\title{
A harcsák neveinek történeti-etimológiai vizsgálata
}

A harcsaalakúak (Siluriformes) rendjébe tartozó harcsafélék családból Európában csak egy faj öshonos. A harcsafélékre a pikkelyek nélküli test, a száj körül lévő 2-3 pár bajusz szál, és a hosszú farokalatti úszó jellemző.

A harcsa igen régröl adatolható halnevünk, 1395 k.: harga (BesztSzj. 289), 1405 k.: harcha (SchlSzj. 786), 1435 k.: horcha (SoprSzj. 128), 1518: harcha, 1527: harchya (OklSz. 349), 1533: harcza (Murm. 1143), 1553: harcha 'Glanis' [Aq.an. 250], 1558: Vngarice hartfcha 'Siluro' [Hist.An. 871], „Silurus Vngerice dicitur harcha" [uo. 873], 1584: harchanak, 1586: harchia (SzT. 4: 1078), 1590: harcza (SzikszF. 83), 1613: harcha [Aldrovandi 567], 1633: harcsat, harczat (SzT. 4: 1078), 1640: hartsa (uo. 1: 1215), 1673: harcsa (Com:Jan.33), 1702: hartsa (Miskolczi 350), 1717: harcsa (SzT. 8: 192), 1735: harcsák (uo. 4: 1078), 1754: hardfcha [Richter 731], 1795: hartsa [Allg.Pol-Lex. 4: 1297], 1774: harcsa (SzT. 4: 1078), 1791: hartsa (Dugonics 1:201), 1798: hardfcha [Donndorf 585], 1801: hartsa (Term. Hist. 259), 1818: uo. (Zsóldos 34), 1830: ua. (Reisinger 29), 1868: harcsa (Kriesch 79), 1882: ua. (Chyzer 6), 1884: ua. 'Silurus glanis' (Nyr. 13: 554). A népnyelvben ÚMTsz. 2: 819 és SzlavSz. 2: 342: harcsa| OrmSz: halcsa 'ua.'.

Conrad Gessner 1558-ban megjelent állattani munkájában olvasható (Hist.An. 4: 873: „Hungari Harcham appellant”), hogy J. Monardus (II. Ulászló és II. Lajos királyok udvari orvosa 1513-19) szerint a „Duna mentén lakó pannóniaiak a Silurust köznyelven Acchiának nevezik, aki úgy látszik, az aspriatiót és az $r$ betüt kihagyta" (MNy. 14: 60). Az ismeretlen eredetű magyar harcsa halnév szlávból (szlovákból) való magyarázata (Beke: Hal. 33: 50), mint arra már Kniezsa (SzlJsz. 839) rámutat, téves. Munkácsi (Ethn. 4: 181) finnugor egyeztetése is elfogadhatatlan. Az sem valószínű, hogy a magyarországi vizek legnagyobb hala a halcsa deminutívumból volna magyarázható. Érdekes, hogy a szláv nyelvekben használatos szom mellé (1. alább) a velünk szomszédos nyelvek átvették a magyar harcsa 'ua.' elnevezést. A ruszinban, románban, szlovákban, szlovénben és ukránban magyar jövevényszóként használatos; vö. ruszin zapч (W.), ro. hárcă, népnyelvi hácă (UngElRum. 404), harc, harcă (Gyurkó 170), szlk. hrča (Ferianc 67; 1887: tót hrca [HalK. 794]), szln. harcsa (TESz. 2: 58), ukr. garč, gárča (Lizanec 587), kárpukr. garč 'ua.' (Владыков 33). A szlovák átvétel korai, már a 18. századból adatolható: hrča, harča, hartsa, hrča ryba 'ua.' (StSl. 3: 87).

A harcsa ném. Wels és Waller (FB.) nevének végső forrása ugyanaz, mint a bálna Wal (Walfisch) nevének, a germ. hwalis (ÖF. 59,10: 238) szóból magyarázható. Az óporosz kalis 'harcsa' (FB.) névböl próbálták megfejteni a mai halnevet, amely egy tengeri hal lat. squalus nevéből ered. A 4. század római költője, Decimus Magnus Ausonius a silurus halat, mint 'a Mosel folyóbeli jámbor bálnánkat' (,nostrae mitis balaena Mosellae”) írta le. A harcsát, a germánok legnagyobb édesvízi halát, a bálnával hasonlították össze. A dánban és a hollandban még ma is van a harcsának meerval (FB.; 1795: meirval [Allg.Pol.-Lex. 4: 1297]), azaz 'tengeri bálna' neve. Conrad Gessner 1670-ben szintén a bálnához kapcsolja a harcsát, azt írja a Wel/3, Wil/3 'Silurus' (Gesnerus red. 4: 190) fajról, hogy „Dief3 fcheuß3liche Thier kònte 
wegen feiner Gestalt teufcher Wallfifch genennet werden [...] ift an der ganzen Gestalt einer Trüfchen nicht ungleich" (uo. 191), vagyis ezt a förtelmes állatot alakja miatt német bálnának is lehetne nevezni, egész alakja egy menyhalra hasonlít. Hozzáteszi még, hogy egy „,cheußslicher grofler fchädlicher Fi ch”, azaz 'förtelmes nagy káros hal'. Ahogy Gessner fogalmazott: „Er hat ein fcheußslich weit maul” (uo. 190), azaz 'förtelmesen széles a szája'. Ezt az erős, nagytestű halat károsnak tartották, mert rengeteg halat pusztít, és úgy hitték, az emberre is veszélyes, ezért kapta Schendfifch (uo.) társnevét.

A ném. Schaden, Schaiden, Schait, Scharn, Scheid, Scheidel (FB.; 1553: Schadem 'Glanis' [Aq.an. 250], 1558: Schaid, Scheid 'Silurus' [Hist.An. 873], 1575: Scheydfifch [Fischb. 183], 1603: ScheideFifch [Schwenckfeld 444], 1613: Schaden [Aldrovandi 567], 1624: Schaidwaller [Icht.Nom. 69], 1666: Scheid [Baldner 143], 1682: Scheiden 'Silurus und Glanis' [Hohberg 2: 512], 1790: Schandfifch [HbDT. 154], 1795: Schaden [Allg.Pol-Lex. 4: 1297], 1798: Schaiden, Scheid [Donndorff 585], Ausztriában Schaden [uo. 587], 1840: an der Donau Scheid [Reichenbach 75], 1858: Schaiden 'Silurus glanis' [Heckel-Kner 308]) halnév az ófn. sceida (W.) név folytatója. A szógyök jelentése 'elválaszt'. A Grimm testvérek azzal magyarázzák, hogy e hal alakja a lovaskard hüvelyéhez hasonló. Az angol nyelvterületen használatos a harcsa ang. sheatfish (FB.; 1776: seatfifh [Müller 4: 290], 1795: Jheat-fifch [Allg.Pol.-Lex. 4: 1298], 1798: scheat fifh [Donndorff 585]) neve, az ang. sheath jelentése szintén 'tok, hüvely'.

Régről adatolható a harcsa északném. Wels, Wils, Wilß, Wölz (FB.; 1558: Wells 'Siluro' [Hist.An. 875], 1575: ua. [Fischb. 183B], 1603: ua. [Schwenckfeld 444], 1624: ua. [Icht.Nom. 69], 1639: Wels [Micraelius 6: 384], 1670: Wel/3 Wil/3 'Silurus' [Gesnerus red. 4: 190], 1682: Welß 'Silurus und Glanis' [Hohberg 2: 512], 1731: Wels [Cur.-Lex. 2201], 1765: Wel/3 [Icht.Bor. 33], 1795: Wels, Wils [Allg.Pol-Lex. 4: 1297], 1798: Wells [Donndorff 585], 1837: Wels [Bujack 341], 1863: Wels in Norddeutschland [Siebold 79], 1869: Welfe [Brehm 5: 478], Wels 'Silurus glanis' [uo. 6: 632]) elnevezése. Átkerült a német terminus más nyelvbe is, szintén 'harcsa' jelentéssel; vö. észt wells (1795: ua. [Allg.Pol.-Lex. 4: 1298], 1798: ua. [Donndorf 586]), ang. wels catfish 'ua.' (FB.).

A - délnémet területen - szintén régröl adatolható a bajor, sváb és az osztrák nyelvjárásokban használatos Waller, Wallerfisch, Welro, Wälin (FB.) terminus első előfordulása egy Tegernsee melletti német szerzetes 1030 körüli írásában adatolható: vualra (ÖF. 59/10: 238), majd 1553: vualer 'Glanis' (Aq.an. 250), 1557: Wälin (Filbüch 42), 1558: Waller, Weller, Wale, Walle, Waellern, Welline 'Siluro' [Hist. An. 874], 1575: Waller, Walline (Fischb. 183b), 1603: Weller (Schwenckfeld 444), 1604: waller (Ges.Med. 874), 1613: Vualler, Vueller (Aldrovandi 567), 1670: Waller, Waller 'Silurus' (Gesnerus red. 4: 190), 1776: Wallerfifch (Mùller 4: 287), 1793: Waller [Schrank 319], 1795: Walin, Wallerfifch (Allg.Pol-Lex. 4: 1297), 1840: in Schwaben und Bayern Waller (Reichenbach 75), 1863: Waller (Siebold 79), 1864: in Bayern Waller, Wäller 'Silurus glanis' (Jäckel 15).

A harcsa finn säkiä (FB.; 1884: säkki [Szinnyei 415]; nyelvjárási säkä, säe [UEW. 469]), észt säga, harilik säga (FB.; sägä, sōgi [UEW. 469]), mordvin сигaл (W.; śije, sijä [UEW. 469]), cseremisz шигол (W.; ši-kol, šij-kol [UEW. 469] (kol 'hal') neve 
etimológiailag a harcsához nagyon hasonló alakú menyhal osztják $s \bar{e} \gamma, s \bar{e} \chi$, vogul

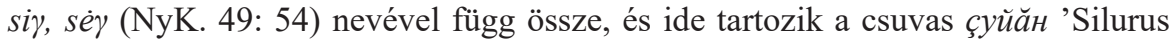
glanis' (W.) halnév is. A harcsa további finnugor neve a vogul vā kar (NyK. 49: 40) és a finn monni (FB.).

A török nyelvekben az etimológiailag szintén összetartozó tatár ж⿻əен (W.; 1795: jain [Allg.Pol.-Lex. 4: 1298]), қаzah жаŭын (W.) és kirgiz жаян (FB.) neve használatos. A skandináv országokban norv. malle (FB.), sv. mal (uo.; 1776: ua. [Müller 4: 290], 1795: ua. [Allg.Pol.-Lex. 4: 1298], 1840: ua. [Reichenbach 75]), dán målle (FB.; 1795: mall, malle [Allg.Pol-Lex. 4: 1298]) néven ismerik.

A latin szaknyelvi Silurus generikus nevet Linné tette érvényesen közzé 1758-ban (Syst.Nat. 1: 501). A nemi név a harcsa latin nevéből való, amelynek a gör. szilurosz 'ua.' a forrása. A latin név folytatója az újlatin nyelvekben a harcsa fr. silure (FB.; 1776: ua. [Můller 4: 290], 1795: ua. [Allg.Pol.-Lex. 4: 1298], 1798: ua. [Donndorf 586]), alb. siluri, ol., port. és sp. siluro (FB.), katalán silur (W.) neve. További ide-

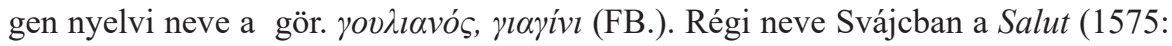
ua. [Fischb. 183], 1603: ua. [Schwenckfeld 444], 1670: ua. 'Silurus' [Gesnerus red. 4: 190], 1840: francia Svájcban saluth [Reichenbach 75]). Több nyelvben - nyilván a bajusz szálai miatt - 'macskahal' a neve; vö. ang. catfish (1865: ua. [Norris 177], 1867: cat-fish [Bouvier 64], 1893: catfish [Georg.Bay 106]), fr. poisson-chat, ol. pesce gatto (W.), port. peixe-gato (FB.). Az Erdélyben, Udvarhely megyében följegyzett népnyelvi szakáli (Szilády 14) név alapja szintén a harcsa hosszú bajusza.

EURÓPAI HARCSA J. Silurus glanis (W.). Mai vizeink legnagyobb testű ragadozó, pikkelyek nélküli, bajuszos hala. Fehér, szálkátlan, fehérjedús húsa igen ízletes.

Honosságára utaló földrajzi neves európai harcsa (1872: európai harcsának [Term. Tud.Közl. 39: 431]) nevének szó szerinti megfelelöje a faj ang. European catfish, or. сом европейский, port. siluro-europeu, dán europceisk malle (FB.), ném. europäischer Wels (W.; 1776: europaif cher Wels [Müller 4: 290], 1784: ua. [Gem.Nat. 5: 125]), ol. siluro d'Europa, holl. europese meerval, norv. europeisk malle, le. sum europejski, szlk. evropski som (W.), fr. silure d'Europe (VN. 10399; 1839: ua. [Cuvier 323]) elnevezése. Minden bizonnyal a német fajnév átvétele tükörfordítással.

Szaknyelvi társneve a lesö harcsa (VN. 10399; 1887: ua. [HalK. 765], 1896: ua. [PallasLex. 12: 84], 1897: ua. [Term.Tud.Közl. 339: 593], 1904: ua. [Prem.gimn. 22], 1905: ua. (BrehmL. 8: 238), 1912: ua. 'Silurus glanis' [Földr.Közl. 171]). Herman Ottó névalkotása 1887-ből, alapja az, hogy ez a faj a zsákmányát az iszapban elfeküdve, alulról lesve ejti el. A folyami harcsa (MoH. 142) társneve a ném. Flusswels (uo.), europäischer Flußwels 'ua.' (FB.) megfelelöje, a 'folyam' földrajzi köznévvel alkotott terminus. A Duna nevével szintén kapott nevet az egyik élőhelyéről; vö. dunai harcsa (VN. 10399; 1881: ua. [ML. 8: 573]), másutt ang. Danube catfish, ném. Donauwels (FB.), azaz 'Duna-harcsa'. Volt a szaknyelvben közönséges harcsa (1849: ua. 'Silurus glanis' [Hanák 39], 1864: ua. [TermRajz. 1: 90], 1868: ua. [Kriesch 142], 1881: ua. [ML. 8: 573], 1884: ua. [Szinnyei 415], 1913: ua. [RévaiLex. 9: 512]) neve is, ennek szó szerinti megfelelöje a faj ném. gemeiner Wels, gewöhnlicher Wels (VN. 10399; 1779: gemeiner Wels [Leske 379], 1792: ua. [Bechftein 1: 719], 1798: ua. [Donndorf 585], 1811: ua. [Kneifl 194], 1841: ua. 'Silurus glanis' [Top.Herz. 14]), or. 
обыкновенный сом, le. sum pospolity, cs. sumес оbecny (FB.), ukr. сом звичайний, fehéror. сом звычайны, litv. aprastasis šamas (W.) neve. A magyar név a német fajnév átvétele.

Hazánk legnagyobb ragadozó halát nevezik parasztfaló (VN. 10399; 1887: ua. [HalK. 765], 1898: ua. [Term. 21: 10], 1919: ua. [Unger 68]) néven is. Noha hetven-nyolcvan kilós példányok még ma is előfordulnak, és a nagy harcsa lehúzza a vízimadarakat, vízi cickány is lehet a zsákmánya, de arra, hogy embert is megtámadott volna - noha több szerző is állította -, nincs konkrét adat. A ponty régi pozsár nevével alkották a pozsárharcsa (VN. 10399; 1717: posár harcsa [SzT. 8: 274]; MTsz. 2: 204: pozsár-harcsa 'Silurus glanis') társnevet. A marosi harcsa (SzegSz. 2: 89) alakja a szokottnál zömökebb. Nem lehet fajnév, a Marosban is csak egy megfigyelt lokálvariációja létezhet a Silurus glanisnak. A sebes harcsa (W.) karcsú testü és fekete, a szőke harcsa (uo.) vagy szürkeharcsa (MoH. 142) világosabb színü. A pumaharcsa (uo.; 1865: puma harcsát [Hunfalvy 3: 737], 1882: pumaharcsa [Nyr. 13: 554]; MTsz. 2: 227: puma-harcsa 'ua.') köznyelvi neve a Tisza, Szamos és a Maros mellékén használatos.

Tiszafüred környékén a tőkésharcsa (Nyr. 1999: 210) az, amely tőkék, víz alatti tuskók körül tanyázik, a kövesharcsa, köviharcsa (uo.) pedig kövezéseken fordul elö. A sárgaharcsa (MoH. 142; 1865: sárga harcsát [Hunfalvy 3: 737], 1887: sárga harcsa 'ua.' [HalK. 825]; OrmSz. 298: ua. 'halfaj' | HalK 825: ua. 'Silurus glanis sárgás színváltozat') színneves név a harcsa egyik helyi változata. Harcsakölyök (ÚMTsz. 2: 853) a fiatal harcsa neve Keszthelyen. A SzlavSz. 2: 342: harcsafi adatának 'ifjú leső-harcsa' a jelentése. A harcsapurdé (Gyurkó 165) 'harcsaivadék'. Tiszafüred környékén a kupak, kupri, kuppancs (W.; Ecsedi 163: harcsakupré) a halászok körében az 1-5 kg közötti kisebb példányokat jelöli, az egész kicsi példánya a harcsapundra (VN. 10399; 1887: ua. [HalK. 795]; MTsz. 1: 810: ua. 'ifjú leső-harcsa' | Dankó 483: pundra 'fiatal harcsa' | Ethn. 49/1-2: 158: pundraharcsa 'kisebb, mint a másik, tiszainak is mondott harcsa, hasalja halovány fehér, háta halovány setétes').

A Silurus glanis moldvai csángó szomn (RK. 537) neve átvétel a románból; vö. ro. somn 'ua.' (FB.; 1909: somn moacă, somotei [Antipa 98]; népnyelvi Gyurkó 170: codoiu de somn / Siret mente, somnicas / Bánát, somnotei, sormotei / Tecuci, somotei / Tighina-Chircaesti 'ua.'). A román szó pedig szláv eredetü, az összes szláv nyelvben megvan a harcsának ez a neve; vö. or. сом (FB.; 1607: ua., 1618: соме [RF. 126], 1795: som [Allg.Pol.-Lex. 4: 1298], 1798: somi [Donndorf 586]), szln. som, szlk. sumec (FB.), cs. sumec (uo.; 1558: sum 'Silurus' [Hist.An. 873]), le. som (W.; 1388-1420: sum [RF. 126], 1558: sum 'Siluro' [Hist.An. 871], 1776: ua. [Müller 4: 290], 1795: ua. [Allg.Pol-Lex. 4: 1298], 1798: szum [Donndorf 586]), bosnyák, hv. som, fehéror., blg., szerb, ukr. сом 'ua.' (W.), sim, sóma, sum, son, ócseh, óle. som (RF. 125). Több európai nyelvbe is átkerült a szláv halnév; vö. ang. som catfish, litv. šamas (FB.), lett sams (uo.; 1795: sams [Allg.Pol.-Lex. 4: 1298]), tör. szom 'ua.' (1795: ua. [uo.]). A harcsa társneve az oroszban a čertova ryba (RF. 127), azaz 'ördöghal', hiszen a čert 'ördög' (REWb. 3: 328) jelentésü szóval alkották, az or. рыба szónak pedig 'hal' a jelentése. 
A latin szaknyelvi Silurus glanis binóment a fajnak Linné adta 1758-ban (Syst. Nat. 1: 501). A Silurus nemi név a harcsa latin nevéből való, lásd fent. Ugyanakkor a lat. glanis fajnév is a harcsát jelölő régi latin névvel azonos, amely már Pliniusnál olvasható. Jóval később a törökből idézik, 1776: glano 'Silurus glanis' (Müller 4: 290), 1798: ua. (Donndorf 586), és megvan a franciában is a harcsa glane (FB.) neve. Igen komoly méretére utal cs. sumec velký (FB.) neve a 'nagy' faji jelzővel, a szlk. sumec západný (W.) nevének 'nyugati harcsa' a jelentése. Több társneve is van a románban és a törökben; vö. ro. iaprac, iarma, moaca, somn-pana, tör. adaty lakga, valamint bayağı yayın balığı (uo.), yayin balığı (FB.), amelyekben a balı̆̆ $l$ szónak 'hal' a jelentése.

ELEKTROMOSHARCSA J. Malapterurus electricus (Akv.Lex.). A trópusi Afrika édesvizeiben honos. $120 \mathrm{~cm}$ hosszúra és $20 \mathrm{~kg}$-osra is megnőhet.

1801: sérész hartsa 'Silurus electricus' (Term.Hist. 259), 1818: ua. (Bonnet 242), 1893: elektromos harcsa 'ua.' (PallasLex. 1: 424), 1898: ua. (Term.Tud.Közl. 348: 414), 1912: ua. 'Malapterurus electricus' (RévaiLex. 6: 317), 1924: ua. (uo. 9: 484), 1931: ua. (Term.Tud.Közl. 930: 257). Magyar neve a faj ném. elektrischer Wels (FB.; 1792: elektri cher Wels [Bechftein 1: 721]) tükörfordítása, további megfelelöje a fr. silure électrique, or. сом электрический, le. sum elektryczny, fi. sähkömonni, észt harilik elektrisäga, ang. electric fish (FB.), electric catfish, katalán peix gat elèctric, dán elektriske mall, port. peixe-gato-elétrico, siluro-elétrico, blg. африкански електрически сомов, litv. elektriniai šamai, ukr. електричний сом звичайний 'ua.' (W.). A névadási szemlélet háttere az, hogy ez a hal képes elektromos teret generálni, akár 400 volt feszültségig. Jól fejlett elektromos szervével villamos ütést tud mérni támadójára vagy kiszemelt zsákmányára. Hasonneve a villamos harcsa (1837: villányos harcsa vagy sérész 'Silurus electricus' (Tud.Tár. 1: 314), 1898: villamos harcsa (Term.Tud.Közl. 348: 414), 1926: ua. 'Malapterurus electricus' (uo. 19: 347), 1927: ua. (TolnaiÚj. 6: 129), 1930: ua. (BrehmL. 14: 273). A faj latin szaknyelvi Malapterurus electricus binominális nevét Gmelin tette érvényesen közzé 1789ben. A latin electricus faji jelző is a hal villamos kisülési képességére utal, amelyet felhasznál a tájékozódásban, a kommunikációban, a védekezésben és a táplálékszerzésben. A Malapterurus nemi nevet a gör. mala 'sok' és gör. pteron 'uszony', valamint a gör. oura 'farok' szavakkal alkották.

A faj élettani hatására utal két korábbi neve is; vö. zsibbasztó harcsa (1893: ua. 'Malapterurus electricus' [PallasLex. 1: 423]), valamint sajgató harcsa (1846: ua. [Hond. 3: 43], 1878: ua. [Nyr. 217], 1881: ua. [ML. 8: 573], 1893: sajgató harcsát (PallasLex. 1: 83), 1897: sajgató harcsa [uo. 14: 796], 1924: ua. [RévaiLex. 16: 484]). És ugyanez a névadási szemlélet háttere a faj ném. Zitterwels (FB.; 1779: Zitter-wels 'Silurus electricus' [Hb.Nat. 293], 1792: ua. [Bechftein 1: 721], 1798: ua. [Donndorf 587], 1801: 3itterwels 'ua.' (Term.Hist. ), 1881: Zitterwels 'Malapterurus electricus' [ML. 8: 573]), holl. siddermeerval (W.), sv. darrmal (FB.), azaz 'rezgetőharcsa' nevének is. És hasonló fr. trembleur, valamint port. peixechoque (uo.), azaz 'rázó, illetve sokkoló hal' elnevezése is. Az ókori egyiptomiak jól ismerték az elektromosharcsát, néhány idegi alapú betegség gyógyítására fel is használták. A Nílus medencéjében régen gyakori volt, földrajzi névvel erre az élőhelyére 
utal fr. poisson-chat électrique du Nil és ro. somnul electric de Nil (W.), azaz 'nílusi elektromos harcsa' elnevezése.

KÉKPAJZSOS PÁNCÉLOSHARCSA J. Corydoras aeneus (W.). A legkedveltebb akváriumi páncélosharcsa. Dél-Amerikában honos. Sekély, gyenge sodrású vizek lakója.

1801: pántcélos hartsa 'Silurus cataphractus' (Term.Hist. 259), 1939: páncélosharcsa (Áll.Közl. 36: 192). 5-8 cm hosszú, bronzszínű testét két sor zöldeskék színü csontlemez fedi, a kopoltyúfedő a szemek alatt szintén zöldeskék. A színneves faji jelző erre utal, a testét fedő csontlemezről pedig a páncélos előtagot kapta. Ugyancsak ez a névadási szemlélet a faj ném. Metall-Panzerwels (FB.; 1801: Panzerwels 'Silurus cataphractus' (Term.Hist. 259), Goldstreifenpanzerwels, dán kobberpansermalle és sv. metallpansarmal (FB.) neve esetében. A köznyelvben házmesterhalnak vagy házmesterharcsának (W.) is hívják.

A latin szaknyelvi Corydoras aeneus binómenben a lat. aeneus 'bronzos, rezes’ faji jelző a hal bronzszínü testére utal, akárcsak sp. corydora bronceada (uo.), ang. bronze catfish, bronze corydoras, fr. corydoras bronze, le. kirysek spirzowy metaliczny, brazíliai port. enéus, észt vask-kiiversäga, fi. kuparimonni (FB.) neve. A lat. Corydoras nemi nevet a gör. kory 'sisak' és a gör. dorasz 'bör' szavakkal alkották, ezzel a névvel jelölik ezt a halat néhány nyelvben; vö. fr. corydoras, brazíliai port. corídora (uo.), sp. corydora (W). Honosságra utal a fi. venezuelanmonninen (FB.), vagyis 'venezuelai harcsák' terminus. Társneve az angolban a wavy catfish és lightspot corydoras (uo.), azaz 'hullámos hal', illetve 'fényes folt'. Az élöhelyén sp. caracha, doradillo, tachuela, pirá-itá (uo.), brazíliai port. camboatazinho, dunda, limpa planta, sarro és tamuata néven ismerik. Az alsó állású szájon három pár bajuszszál van, ezek tapogatóként szolgálnak. A szabadban érzékeny bajsza segítségével is képes megtalálni az iszapban megbúvó férgeket, ezért kapta fr. fouilleur (uo.), vagyis 'kotrógép' nevét.

FEKETE TÖRPEHARCSA J. Ameiurus melas (HN.). Észak-Amerika középső és keleti részén őshonos, Európába a törpeharcsával együtt került be. Magyarországon tógazdaságból terjedt el.

1989: ua. (MoH. 15). Magyar neve a faj ném. schwarzer Zwergwels, schwarzer Katzenwels, ang. black catfish (FB.), black bullhead (uo.; 1901: ua. 'Ameiurus melas' [Ann.Rep. 480]), dán sort dvaergmalle, sv. svart dvärgmal, fr. barbotte noire, le. sumik czarny, észt must kärpsäga, must kasssäga, fi. mustapiikkimonni (FB.), holl. zwarte dwergmeerval (W.) nevének megfelelője. Bővítményekkel ellátott ugyan, de szintén ennek a törpeharcsának a színére utal az ang. black bullhead catfish (uo.), holl. zwarte amerikaanse dwergmeerval, sp. bagre torito negro (FB.) terminus. A latin melas faji jelzőnek ugyancsak 'fekete' a jelentése.

Tiszafüred környékén a fekete törpeharcsa - nyilván mert régebben ismeretlen, újabb jövevény - új törpeharcsa (Nyr. 1999: 210) elnevezést kapott. A bikaszarvakhoz hasonló hajlított, felfelé álló bajuszpárra utal a szarvas jelző megfelelöjével kanadai ang. hornedpout (FB.) elnevezése. Kanadában színneves jelzővel yellow belly bullhead (uo.), azaz 'sárgahasú ebihal' néven is ismerik, ennek alapja szennyes- 
sárga hasa. A latin szaknyelvi Ameiurus nemi névben a gör. $a$ fosztóképző, a gör. meiourosz szó jelentése 'farok nélküli', a hal tompa, uszony nélküli farkára utal.

TÖRPEHARCSA J. Ictalurus nebulosus (MoH. 138). Észak-Amerikában őshonos. Teste a harcsáénál zömökebb, és sokkal kisebb. Aránylag nagy feje széles, elöl lapos.

Európai honosítása 1885-ben kezdődött. 1905: törpeharcsát (Ujság 187), 1906: angol törpeharcsát (Közt. 03), 1908: amerikai törpeharcsát (uo. 87), 1910: törpe harcsa 'Amiurus nebulosus' (Term.Tud.Közl. 498: 83), 1915: ua. (uo. 619-620: 115), 1925: ua. (RévaiLex. 18: 427), 1930: ua. (BrehmL. 14: 271), 1939: törpeharcsa (Hal. 13: 80). A népnyelvben Népr.Közl. 4,3: 42: ua. (Lónya)| Unger 70: ua. (tógazdaságokban). A törpeharcsa terminus névátvitel eredménye, mivel e hal a külső jegyeiben a harcsára emlékeztet. Teste azonban jóval kisebb, innen a faji jelző. Számos európai nyelvben megvan a faj megfelelő neve; vö. ném. Zwergwels, dán dvaergmalle, norv. dvergmalle, sv. dvärgmal, észt harilik kass-säga, ro. somn pitic (FB.), holl. dwergmeerval, fi. piikkimonni, ro. somn pitic 'ua.' (EL.). A lengyelben sumik karłowaty (FB.), azaz 'csenevészharcsa' a neve. Tiszafüred környékén törpincs (Nyr. 1999: 211) néven is emlegetik.

Társneve a népnyelvi kuszaharcsa (MoH. 138; Dankó 475: ua.). A törpeharcsára sokszor dühös horgászok adhatták az istenverte hal (Halh. 48) terminust ennek a kicsi, de rendkívül mohón kapó halnak. Széles, lapos fejére és a bikaszarvakhoz hasonló hajlított, felfelé álló bajuszpárra utal az ang. bullhead (EL.; 1888: catfish bullhead 'Ictalurus' [Am.F. 376], 1901: common bullhead [Ann.Rep. 480], 1904: ua. 'Ameiurus nebulosus' [Am.Nat.Hist. 416]), azaz 'bikafej' elnevezés, valamint a szarvas [szarvval ellátott] jelzővel a ro. biş cu coarne (W.), bici-cu-coarne (FB.), ang. horned pout, hornpout (uo.; 1904: horned pout 'Ameiurus nebulosus' [Am.Nat. Hist. 416]) társneve. A faj amerikai származása volt a névadás alapja földrajzi neves ro. somn american, or. американский сомик, ném. amerikanischer Zwergwels, or. американский сомик, cs. sumecek americký, holl. bruine amerikaanse dwergmeerval (FB.), szerb амерички сомић (W.) nevének. Háta sötétbarna, oldala felül sötétbarna, lefelé fokozatosan világosabbra válik, erre utalnak a barna színnévvel a törpeharcsa port. peixe-gato-cabeçudo-castanho, holl. bruine dwergmeerval (uo.), ang. brown bullhead, brown bullhead catfish, brown catfish, northern brown bullhead, fr. barbotte brune, ném. brauner Katzenwels, észt pruun kärpsäga, sv. brun dvärgmal, dán brun dvargmalle (FB.) nevei.

Ma érvényes latin szaknyelvi neve az Ameiurus nebulosus, a néhány éve még

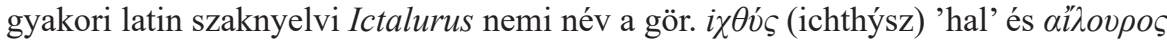
(ailourosz) 'macska' szavakkal alkotott. A magyarban is használatos macskaharcsa (VN. 5840) társneve, de több nyelvben is 'macskahal, macskaharcsa' a neve; vö. port. peixe-gato, tör. kedi yayın balığ $\breve{l}_{l}$ (W.), sp. pez gato, ol. pesce gatto nebuloso (HN.), ang. catfish, mudcat (FB.), fr. poisson chat, ném. Katzenwels, Katzenfisch, ol. pesce gatto, sp. coto pardo (EL.). A lat. nebulosus faji jelzőnek 'füstszürke' a jelentése. Idegen nyelvi neve még a szerb терпан, манић, цвергл, кућин, мањов, бодоња, главоња, роган (W.), szlk. sumcek krpatý, ro. somnicaş, sp. barbú torito (FB.), valamint a fi. piikkimonni (uo.), azaz 'tüskés harcsa'. Böre pikkelytelen, csupasz. oldala szürke, márványozott foltokkal, erre utal a 'márványozott' jelzővel ang. 
marbled bullhead (uo.) neve. Alsó és felső állkapcsán 4-4, összesen 8 bajuszszál van, erre utal ro. opt mustări (W.), azaz 'nyolc bajusszál' elnevezése.

KÉKHARCSA J. Ictalurus furcatus (W.). Észak-Amerika legnagyobb harcsája, 135 cm-es, tömege $20 \mathrm{~kg}$ is lehet. Teste hosszúkás, a nagy fejétől a farokúszójáig vékonyodik.

Magyar neve a faj ang. blue catfish (FB.) nevének tükörfordítása. További megfelelöje a ném. blauer Katzenwels (FB.; 1798: blauer Wels [Donndorf 595]), sp. bagre azul, or. синяя зубатка, fi. sinipiikkimonni, dán blå dvcergmalle (FB.), fr. poisson-chat bleu, ol. pesce gatto azzurro, pesce gatto blu, le. sumik blękitny, ukr. ікталур блакитний 'ua.' (W.). A testének szürkéskék alapszínére utal a faji jelző. A latin szaknyelvi Ictalurus furcatus binóment Georg Cuvier és Achille Valenciennes tette közzé 1840-ben (Cuvier 15: 421). A lat. furcatus 'villa alakú' faji jelzőnek a hal villás farokúszója az alapja.

NÉGYBAJUSZSZÁLAS HARCSA J. Silurus aristotelis (VN. 10398). Görögországban honos, homokos vagy iszapos talajú vizek lakója. Teste átlagosan 100-150 $\mathrm{cm}$, háta sötét.

Felső állkapcsán 2 hosszú bajuszszál, a fej alsó részén szintén 2, csak fele akkora bajuszszál van, ezekre utal nevében a faji jelző. A latin szaknyelvi aristotelis faji jelzőt az első tulajdonképpeni zoológusról, a görög Arisztotelészről, a Historia animalium szerzőjéről kapta ez a hal. 1857-ben tette érvényesen közzé a Silurus aristotelis binóment Louis Agassiz (Proc.Am. 3: 325), ennek alapján jött létre a faj Arisztotelész harcsája (VN. 10398), az or. сом Аристотеля (uo.), ang. Aristotle’s catfish, ném. Aristoteles-Wels, ol. siluro di Aristotele, holl. aristotelesmeerval, ukr. сом Apicтотеля (W.), észt aristotelese säga, le. sum arystotelesa, sv. aristotelesmal (FB.) elnevezése. Honossága alapján kapta másik faji jelzőjét; vö. port. silurogrego, dán grcesk malle, fi. kreikanmonni (uo.), azaz 'görög harcsa'. Tárneve az ang. Acheloos catfish, a görögben $\gamma \lambda \alpha v o ́ \varsigma, ~ \gamma \lambda \alpha v i \delta l$ (uo.) néven ismerik.

TOROKÁTUM HARCSA J. Megalechis thoracata (W.). Dél-Amerikában honos, legfeljebb 15,5 cm hosszú. Zömök testfelépítésü, uszonyai kicsik, szája alsó állású. Nálunk akváriumi díszhal.

A torokátum, toro harcsa (diszhal.info/Megalechis_thoracata.php) nevek a latin szaknyelvi Megalechis thoracata binómenben, illetve a Hoplosternum thorocatum szinonim névben szereplő latin faji jelzőből származnak. Akárcsak a faj ukr. торакатум (W.) és cs. torokatum sumec (http://miskolczoo.hu/allat/torokatumharcsa) elnevezése. A hal az alapszínét környezetétől és hangulatától függően változtatja vörösesbarna, barna és fekete között, de egész testét folyamatosan megmaradó fekete foltok tarkítják. Köznyelvi neve emiatt a foltos páncélosharcsa (www.kislexikon.hu) vagy tarka páncélosharcsa (diszhal.info/Megalechis_thoracata.php). Az európai nyelvekben több neve is használatos a 'pettyes, foltos' jelzö megfelelöivel; vö. ang. spotted hoplo, sp. hoplo moteado, le. kiryśnik czarnoplamy (W.). Szintén több neve is utal a pikkelytelen, sötét börére; vö. ang. black marble hoplo, ném. rehbraune Schwielenwels, gemalte Schwielenwels (uo.). 
Oldalait egymást átfedő lemezek fedik, amelyek vastag csontlemezekké állnak össze, és stabil védőpáncélt alkotnak. Erre utal a faj holl. gevlekte pantsermeerval (uo.) és fi. pistehaarniskamonni (FB.), azaz 'pettyes páncélosharcsa' elnevezése. További neve a sp. hoplo porteño (W.), élöhelyén brazíliail port. atipa, camboatá, cambuí, cascudo, eloí, sete léguas, tamatá, tamboatá (FB.) néven ismerik. A latin szaknyelvi binóment Georges Cuvier és Achille Valenciennes adta a fajnak 1840ben (Cuvier 15: 430), a Megalechis nemi nevet a gör. megasz, megalosz 'nagy' és a gör. echisz, -eosz 'vipera' szóval alkották.

INDIAI ÜVEGHARCSA J. Kryptopterus bicirrhis (W.). Ázsiában honos, Thaiföldön, a Maláj félszigeten és Indonéziában. Igen népszerü akváriumi díszhal.

Magyar nevének szó szerinti megfelelöje a ném. indischer Glaswels, dán indisk glasmalle (FB.), ol. siluro di vetro indiano, holl. indische glasmeerval, norv. indisk glassmalle, or. индийский стеклянный сомик 'Kryptopterus bicirrhis' (W.). Ugyancsak földrajzi neves, és honosságra utal ném. asiatischer Glaswels (FB.), azaz 'ázsiai üvegharcsa' elnevezése. Honossági területén khmer trey kes prak, indonéziai lais limpok, lais tipis és thai pla kang pra ruong, pla kra jok, pla pee sard (uo.) néven ismerik.

A Kryptopterus bicirrhis binóment Cuvier és Valenciennes adta 1840-ben. A latin szaknyelvi Kryptopterus nemi név a gör. kryptosz 'rejtett' és gör. pteron 'szárny, uszony’ szavakkal jött létre. 2013-ban a svájci ichthyológus, Maurice Kottelat és szingapúri kollégája, Ng Heok Hee elkülönített egy eddig még senki által le nem írt, a 15 cm-es Kryptopterus bicirrhis fajnál kisebb, mindössze 5,5-6,5 cm-es fajt, és adták neki az azóta érvényes latin szaknyelvi Kryptopterus vitreolus binóment. A latin vitreolus faji jelző a latin vitréus 'üveg' kicsinyítő képzős alakja, ennek a fajnak a teste ugyanis üvegszerüen átlátszó. A díszhal-kereskedelemben erre a fajra vonatkoznak a nevek. Az észtben harilik vikersäga (FB.), vagyis 'közönséges boszorkányharcsa', földrajzi neves faji jelzö nélkül, csak 'üvegharcsa' a jelentése ang. glass catfish, fi. lasimonni, sundanlasimonni, sv. glasmal, le. sumik szklisty (uo.), sp. pez gato de cristal, siluro de cristal fr. silure de verre, ol. oltretomba, le. sumiczek szklisty, sumek szklisty, port. peixe-gato de vidro, ro. peștele de cristal, szerb stakleni som, sv. glasmal, tör. cam kedibalığ (W.) nevének. További neve az ukr. сомік двовусий, valamint az ang. phantom fish, ol. pesce fantasma (uo.), azaz 'szellemhal'.

CSATORNAHARCSA J. Ictalurus punctatus (W.). Észak-Amerika fontos tógazdasági haszonhala, ma már másutt is tenyésztik. Magyarországra 1975-ben került.

Magyar csatornaharcsa neve a faj ang. channel catfish (FB.; 1877: channel cat 'Ichthaelurus' [Bull. 1,10: 75], 1901: ua. [Ann.Rep. 480], 1919: channel-catfish 'Ictalurus punctatus' [Henshall 244]), or. сом канальный, ro. somn de canal, sp. bagre de canal, blg. kanalen som, észt kanalisäga, dán kanalmalle (FB.), le. sumik kanałowy, sum kanałow, holl. kanaalmeerval (W.) nevének a megfelelöje. A hal többféle vízben megél, folyókban, vízgyüjtőkben, tavakban és kisebb mesterséges vizekben is, egyik élöhelyére utal fr. barbue de rivière (FB.) neve is a 'folyami' jelzővel. 
Társneve a pettyes harcsa (W.), pettyes törpeharcsa (VN. 5841). A latin szaknyelvi binómenben a lat. punctatus faji jelzőnek is 'pettyes' a jelentése. A testen látható sötét foltokra utal, akárcsak or. пятнистылй сомик (uo.), ol. pesce gatto punteggiato, dán plettet dvargmalle, ro. somn patat, cs. sumecek teckovaný, sp. barbú moteado, fi. pilkkupiikkimonni (FB.) nevében a faji jelző. A ném. getüpfelter Gabelwels, sv. prickig dvärgmal (uo.) nevének pedig 'pettyes villásharcsa', illetve 'pettyes törpeharcsa' a jelentése. A litvánban baltoji katžuve (W.) 'fehér csatornaharcsa', az Egyesült Államokban ang. graceful catfish (FB.), azaz 'kecsesharcsa' néven is ismert. Amerikai honosságára utal fr. barbue d'Amérique és port. bagre americano (uo.) elnevezése.

AFRIKAI HARCSA J. Clarias gariepinus (W.). Afrikában és Kis-Ázsiában őshonos. Hazánkban csak termálvizekben vagy az erőmüvek tavaiban lehet tenyészteni. Gyorsan nő.

Összetett nevében az afrikai faji jelző eredeti élöhelyére utal. A generikus nevet lásd a harcsa szócikkében. Számos idegen nyelvi nevét ugyancsak honossága, származása alapján kapta; vö. fr. poisson-chat nord-africain, ném. afrikanischer Raubwels, or. сом клариевый африканский, brazíliai port. bagre-africano, dán afrikansk ålemalle (FB.), ol. pesce gatto africano, sp. pez gato africano, ang. North African catfish (EL.), African walking catfish, sv. afrikansk vandrarmal, cs. zvaný též sumeček africký, fr. poisson-chat africain, le. sum afrykańsk, holl. afrikaanse meerval (W.).

Ugyancsak földrajzi névvel keletkezett or. нильский клариа, ukr. кларій нільський (W.), ill. ang. Philippine catfish, Thailand catfish (EL.), azaz 'nílusi klarias', illetve 'Fülöp-szigeteki / thaiföldi harcsa' neve. Az ang. sharptooth catfish, sharptoothed catfish (FB) és a ném. Scharfzahnwels (W.) elnevezésének 'élesfogú harcsa' a jelentése. További neve a le. tawada, stawada, a vörös színnévvel alkotott cs. keříčkovec červenolemý, a márványos jelzővel a pikkelytelen, csupasz testére utaló or. мраморный клариевый сом (uо.) neve, a más, hasonló testalkatú halfaj nevével alkotott, és megnyúlt, hengeres testére utaló sv. ålmal 'angolnaharcsa' (EL.) és a ném. Aalbüschelwels 'angolna bojtosharcsa' (FB.) összetétel. A nagy jelzö megfelelőjével alkották észt suur angersäga (uo.), azaz 'nagy haragharcsa' nevét. A finnben konnamonni (EL.), jättikonnamonni (FB.), vagyis '[óriás] gazemberharcsa' néven ismert. Nagy és végállású szája körül nyolc bajuszszál található, erre utal tör. sekiz biyik (uo.), azaz 'nyolcbajusz' elnevezése. 'Vándorharcsa' a jelentése dán vandremalle, sv. asiatisk vandrarmal, ném. Wanderwels (EL.) elnevezésének.

A latin szaknyelvi Clarias nemi név a gör. chlarosz 'élénk, eleven' szóval jött létre, és arra utal, hogy az afrikai harcsa hosszú ideig megél a vízen kívül is. A kopoltyúüreg zacskószerü képződményeinek segítségével ugyanis a légköri oxigént is fel tudja venni. Ezért az oxigénben szükös, időszakos vizekben is megél, emiatt kapta ang. mudfish 'sárhal, iszaphal' és tör. karabalik 'földhal' (FB.) nevét is. A latin genusnévböl szár-

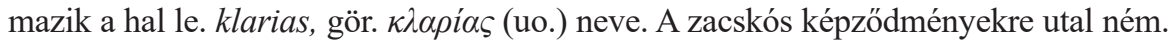
Kiemensackwels 'kopoltyúzacskós harcsa' (uо.) és or. сом клариевый 'zacskósharcsa' (EL.) elnevezése is. A latin gariepinus faji jelző a faj egyik élöhelye, a Gariep folyó, a Dél-afrikai Orange river hottentotta nevéből származik. 


\section{HIVATKOZÁSOK}

Akv.Lex. $=$ Akvarista Lexikon: https://akvaristalexikon.hu

Aldrovandi $=$ Ulyssis Aldrovandi ... De piscibus libri V et De cetis lib. unus. Bononiae, 1613.

Allg.Pol.-Lex. $=$ Philipp Andreas Nemnich: Allgemeines Polyglotten-Lexicon der NaturGeschichte. Hamburg, 1793-1798.

Am.F. $=$ George Brown Goode: American fishes. New York, 1887-88. 2. ed. Boston, 1903.

Am.Nat.Hist. = William T. Hornaday: The American natural history. London,1904.

Ann.Rep. = Annual report of the Commissioners of Fisheries, Game and Forests of the ... Albany, 1896-1901.

Antipa = Grigore Antipa: Fauna ichtiologică a româniei. Bucuresti, 1909. https://doi. org/10.5962/bhl.title.64333

Aq.an. = Ippolito Salviani: Aquatilium animalium historiae, liber primus: cum eorumdem formis, aere excusis. Rom, 1553.

Baldner = Leonhard Baldner: Recht natürliche Beschreibung und Abmahlung der WasserVögel, Fischen... Strassburg, 1666.

Bechltein = Johann M. Bechltein: Kurzgefajste gemeinnütsige Thiergefchichte des In- und Auslandes. Leipzig, 1792-. https://doi.org/10.5962/bhl.title.101829

Bonnet $=$ Charles Bonnet: A’ természet vizsgálása. Ford.: Tóth Pál. Pest, 1818.

Bouvier $=$ Hannah M. Bouvier: The family save-all.: Supplying excellent dishes for breakfast, dinner ... Philadelphia, 1867.

BrehmL. $=$ Brehm Alfréd: Az állatok világa. 14. A hazai viszonyokra alk. Leidenfrost Gyula. Budapest, 1930.

Bujack = Johann Gottlieb Bujack: Naturgeschichte der höheren Thiere mit besonderer ... Königsberg, 1837.

Bull. $=$ Bulletin - United States National Museum. Washington, 1877-1971.

Chyzer = Chyzer Kornél: Zemplénmegye halai. Igló, 1882.

Com:Jan. = Johann Amos Comenii Janua linguae latinae. Leutschoviae, 1643. Kolozsvár, 1673.

Cur.-Lex. = Johann Hübner: Curieuses und Reales Natur-Kunft-Berg-Gewerck- und Handlungs-Lexicon. Hamburg, 1731.

Cuvier $=$ Georges Cuvier - Achille Valenciennes: Histoire naturelle des poissons. Paris, 1828 1849.

Dankó = Dankó Imre: Bodrogközi halászszótár. A miskolci Herman Ottó Múzeum Évk. XI: 449-504. 1972.

Donndorff $=$ Zoologi che beyträge zur ... von Johann August Donndorff. III. Leipzig, 1798.

Dugonics = Dugonics András: Etelka. I-II. Posony, Pest, 1791.

Ecsedi = Ecsedi István: Népies halászat a Közép-Tiszán és a tiszántúli kisvizeken. Debrecen, 1933.

EL. = Encyclopedia of life. (A legnagyobb biológiai adatbázis) http://www.eol.org

Ethn. = Ethnographia . Budapest, 1890- .

FB. = Fischbase. A global species database of fish species. www.fishbase.org/search.php (hozzáférés: 2017. júl.).

Ferianc = Oskár Ferianc: Slovenské názvoslovie ryb Československej republiky ... Turčiansky Svätý Martin, 1948.

Filbüch = Gregor Mangolt: Fifbüch von der Natur und Egenfchafft der Vifche. Zürych, 1557.

Fischb. = Conrad Gessner: Fischbuch, das ist ein kurze, doch vollkommne ... Zurich, 1575; Franckfurt am Meyn, 1598. 
Földr.Közl. = Földrajzi Közlemények. Budapest. 1873-1948. 1953 -.

Gem.Nat. = G. H. Borowski: Gemeinnüzzige Naturgeschichte des Thierreichs. 5. Bd., von den Fischen. Berlin, 1784.

Georg.Bay = James C. Hamilton: The Georgian Bay. An account of its position ... Toronto, 1893.

Ges.Med. = Conradi Gesneri medici Tigurini Historiae animalium liber IV: qui est De piscium ... Francofurti, 1604.

Gesnerus red. = C. Gesner - C. Forer - G. Horst: Gesnerus redivivus auctus \& emendatus. Vol. 4. Frankfurt a. M., 1670.

Gyurkó = Gyurkó István: Édesvizi halaink. Bukarest, 1972.

Hal. = Halászat. Budapest, 1932-.

Halhat. = Pintér Károly: Halhatározó. Budapest, 1989.

HalK. = Herman Ottó: A magyar halászat könyve I-II. Budapest, 1887.

Hanák = Hanák János: Az állattan története és irodalma Magyarországban. Pest, 1849.

Hb.Nat. = Johann Friedrich Blumenbach: Handbuch der Naturgeschichte. Göttingen-Wien, $1779-1832$.

HbDT. $=$ Handbuch der deutschen Thiergeschichte für Schulen . Gießen, 1790.

Heckel-Kner = Jacob Heckel - Rudolf Kner: Die Süsswasserfische der östreichischen Monarchie. Leipzig, 1858.

Henshall = James A. Henshall: Bass, pike, perch and other game fishes of America . Cincinnati, 1919. https://doi.org/10.5962/bhl.title.40113

Hist.An. = Conradi Gessneri ... Historice Animalium Liber IIII. qui est de Piscium [et] Aquatilium ... Zürich, 1558.

$\mathrm{HN} .=$ Halak nevei öt nyelven. Tarka bárka (http://tarkabarka.cafeblog.hu/szotarak)

Hohberg = Wolf Helmhard von Hohberg: Georgica Curiosa. Bd. 2. Nürnberg, 1682.

Hond. = Honderü. Pest, 1843-1848.

Hunfalvy = Hunfalvy János: A magyar birodalom. III. Pest, 1865.

Icht.Bor. = Johan. Christoph. Wulff: Ichthyologia cum Amphibiis regni Borussici. Regiomonti, 1765.

Icht.Nom. = Stephanus Schonevelde: Ichthyologia et Nomenclaturae animalium marinorum, fluviatilium ... Hamburgi, 1624.

Jäckel = Andreas J. Jäckel: Die Fische Bayerns. Abhand. des zool.-mineral. Vereines in Regensburg. 9. 1864.

Kneifl = Reginald Kneifl: Das Thierreich; Ein Handbuch fur die Hörer der Philofophie. Wien und Trieft, 1811.

Közt. = Köztelek. Az OMGE közlönye, köz- és mezőgazdasági lap. Budapest, 1891-1944.

Kriesch $=$ Kriesch János: Halaink és haltenyésztésünk. Pest, 1868.

Leske = Nathanael G. Leske: Anfangsgründe der Naturgeschichte. 1. Algemeine Natur- und Tiergeschichte. Leipzig, 1779.

Lizanec $=$ P. M. Lizanec: Vengerszkije zaitctbotbanija v ukrainszkih govorah zakarpatija. Budapest, 1976.

Micraelius = Johann Micraelius: Sechstes vnd Letztes Buch Von deß Pommerlandes Gelegenheit... Stettin, 1639.

Miskolczi = Miskolczi Gáspár: Egy jeles vadkert . Lőcse, 1702.

ML. = Magyar Lexikon. Budapest, 1878-1882.

MoH. = Pintér Károly: Magyarország halai . Budapest, 1989.

Mưller = Philipp Ludwig S. Mưller: Des Ritters Carl von Linné vollltändigen Naturfystem $1 . .$. Nưrnberg, 1776.

Népr.Közl. = Néprajzi Közlemények. Adatközlő néprajzi folyóirat. Budapest, 1956-. 
Norris $=$ Thaddeus Norris: The American angler's book. Philadelphia, 1865 .

ÖF. $=$ Österreichs Fischerei. Zeitschrift für die gesamte Fischerei. Mondsee, 1947-.

Prem.gimn. $=$ Premontrei katolikus fögimnázium. Iskolai értesítő. Keszthely, 1904.

Proc.Am. $=$ Proceedings of the American Academy of Arts and Science. 1-85. Boston, 18461958.

Reichenbach = Anton Benedikt Reichenbach: Die Fi I che: dargestellt in getreuen Abbildungen und mit ... Leipzig, 1840.

Reisinger = Joannes R. Reisinger: Specimen ichthyologiae. Buda, 1830.

RF. = Irmgard Leder: Russische Fischnamen. Wiebaden, 1971.

Richter = Johann Gottfried Richter: Ichthyotheologie, oder: Vernunft- und Schriftmå $\int_{3} i g e r$ Versuch... Leipzig, 1754.

RK. = Márton-Péntek-Vöö: A magyar nyelvjárások román kölcsönszavai. Bukarest, 1977.

Schrank $=$ Franz von Paula Schrank: Reise nach den südlichen Gebirgen von Bayern. München, 1793.

Schwenckfeld = Caspar Schwenckfeld: Therio-Tropheum Silefiae: in quo animalium ... Lignicii [Liegnitz], 1603.

Siebold = Carl Theodor von Siebold: Die Süsswasserfische von Mitteleuropa. Leipzig, 1863.

StSl. = Studia slavica . Budapest, 1955-. https://doi.org/10.5962/bhl.title.61814

Syst.Nat. = Caroli Linnaei...Systema naturae per regna tria naturae: secundum classes, ordines ... Holmiæ, 1758-1759.

Szilády = Szilády Zoltán: A magyar népnyelv állatnevei. Temesvár, 1907.

Szinnyei = Szinnyei József, ifj.: Finn-magyar szótár. Budapest, 1884.

Term. $=$ A Természet . Budapest, 1897- .

Term.Hist. $=$ Földi János: Természeti história . Pozson, 1801.

Term.Tud.Közl. = Természettudományi Közlöny. Budapest, 1869-1944.

TolnaiÚj. = Tolnai Új Világlexikona. 1-22. Budapest, 1926-1933.

Top.Herz. $=$ Johannes von Schröder: Topographie der Herzogthums Holltein. Oldenburg, 1841.

Tud.Tár. = Luczenbacher János (szerk.): Tudománytár 1. köt. Pest, 1837.

Ujság = Ujság. Budapest, 1904-1943.

UngElRum. = Lajos Tamás: Etymologisch-historisches Wörterbuch der ungarischen El.. Budapest, 1966.

Unger = Unger Emil: Magyar édesvízi halhatározó. Budapest, 1919.

Владыков = Вадим Владыков: Обычные названия рыб ... Просвите, 5: 205-232. Ужгород, 1927.

VN. = Gozmány László: Vocabularium nominum animalium Europae septem linguis red. $\mathrm{Bu}-$ dapest, 1979.

W. = Wikipedia, the free encyclopedia (http://...wikipedia.org).

Rácz János

https:// orcid.org/0000-0002-9473-1319 